\title{
PENGARUH RETROGRADASI DAN PERLAKUAN KELEMBABAN PANAS TERHADAP KADAR PATI RESISTEN TIPE III DALUGA
}

\author{
[Effect of Retrogradation and Heat Moisture Treatment to Resistant Starch Type III \\ Daluga Corm Content]
}

\author{
Agustina $^{1) \star}$, Didah Nur Faridah ${ }^{2)}$, dan Betty S. L. Jenie ${ }^{2)}$ \\ 1) Program Studi Ilmu Pangan, Sekolah Pasca Sarjana, Institut Pertanian Bogor, Bogor \\ 2) Departemen Ilmu dan Teknologi Pangan, Fakultas Teknologi Pertanian, Institut Pertanian Bogor, Bogor
}

Diterima 28 Maret 2016 / Disetujui 28 Juni 2016

\begin{abstract}
The giant swamp taro starch or daluga corm starch in this study was extracted from corms collected from Siau Island of North Sulawesi Province in Indonesia. Native starch daluga corm has low resistant starch content, so starch modifications method were needed to increase its resistant starch content. The effect of acid hydrolisis, deb ranching, autoclaving-cooling and heat moisture treatment on the changes of $R S 3$ daluga were studied. The corrm starch was first modified with acid hydrolysis $(H A)$ and debranching with pullulanase (D). The starch was then modified with one cycle autoclaving-cooling (HADAC1X), $H A D A C 1 x$ with heat moisture treatment (HADAC1x+HMT), three cycle autoclaving-cooling (HADAC3x), HADAC3x with heat moisture treatment (HADAC3x+HMT) which increased its RS3 content to 42.37, 40.47, 31.12, and 31.18\% (db), respectively. The starch modification method can affect other chemical properties changes such as starch content, amylose content, and reducing sugar content.
\end{abstract}

Keywords: daluga corm starch, modified starch method, RS3

\section{ABSTRAK}

Pati talas raksasa atau pati umbi daluga yang digunakan dalam penelitian ini diekstraksi dari umbi yang diperoleh dari Kepulauan Siau, Sulawesi Utara, Indonesia. Pati alami (tanpa modifikasi) umbi daluga memiliki kadar pati resisten yang rendah, sehingga dibutuhkan beberapa metode modifikasi pati untuk meningkatkan kadar pati resisten dalam pati daluga. Melalui penelitian ini, dilakukan pengkajian tentang pengaruh hidrolisis asam, debranching, autoclaving-cooling, dan heat moisture treatment terhadap perubahan kadar pati resisten tipe III (RS3) pati daluga. Pati umbi daluga terlebih dahulu dimodifikasi dengan hidrolisis asam (HA), debranching with pullulanase (D). Pati daluga hasil modifikasi tersebut dimodifikasi dengan autoclaving-cooling 1 siklus (HADAC1x), HADAC1x dengan heat moisture treatment (HADAC1 $+\mathrm{HMT}$, autoclaving-cooling 3 siklus (HADAC3x), HADAC3x dengan heat moisture treatment (HADAC3x+HMT) yang dapat meningkatkan kadar RS3 masing-masing hingga 42,37; 40,47; 31,12 dan $31,86 \%$ (bk). Metode modifikasi pati juga dapat mempengaruhi perubahan karakteristik kimia pati modifikasi lainnya seperti kadar total pati, kadar amilosa, dan kadar gula pereduksi.

Kata kunci: metode modifikasi pati, RS3, pati umbi daluga

\section{PENDAHULUAN}

Talas raksasa atau umbi daluga (Cyrtosperma merkusii) merupakan salah satu jenis tanaman talas-talasan yang tumbuh di Kepulauan Siau, Manado, Provinsi Sulawesi Utara, Indonesia. Sebagian besar varietas harus diregenerasi ketika berumur 3 tahun dan tumbuh hingga ketinggian 3-4 $\mathrm{m}$, dengan umbi 5-10 kg. Namun, tanaman umbi daluga dapat tetap berada di dalam tanah selama

${ }^{*}$ Penulis Korespondensi:

E-mail: agustina.atina17@gmail.com
10-15 tahun atau lebih, bahkan hingga 30 tahun, tanpa mengalami perubahan yang berarti (Jackson, 2008). Tanaman umbi daluga ini belum dibudidayakan oleh masyarakat setempat, sehingga sejauh ini belum ada data mengenai produktivitas tanaman umbi daluga tersebut. $\mathrm{Di}$ samping itu, pemanfaatan umbi daluga ini masih terbatas sebagai bahan makanan pokok yang diolah secara tradisional baik dikukus maupun digoreng. Masyarakat setempat mengonsumsi umbi daluga sebagai sumber karbohidrat pengganti beras. Berdasarkan hasil analisis proksimat tepung daluga memiliki kadar air $4,78 \%$, kadar abu $3,5 \%$, lemak $0,14 \%$, 
protein 10,09\%, dan karbohidrat 81,45\%. Kandungan karbohidrat khususnya pati dalam umbi daluga tersebut dapat dimanfaatkan sebagai bahan baku pembuatan pati resisten tipe III. Seperti halnya pada pati garut yang dapat dimodifikasi secara fisik dan kimia menghasilkan pati resisten tipe III hingga 39,3\% (Faridah, 2011).

Pati merupakan polisakarida yang terdiri dari dua jenis molekul yaitu amilosa (poliglukan rantai lurus yang terdiri dari \pm 1000 a-D-(1-4) unit glukosa); dan amilopektin (glukan bercabang yang terdiri dari \pm 4000 unit glukosa dengan cabang pada ikatan $\alpha$-D(1-6), dan a-D-(1-4) (Sharma et al., 2008). Berdasarkan daya cernanya, terdapat 3 kelompok pati yaitu rapidly digestible starch (RDS), slowy digestible starch (SDS), dan resistant starch atau pati resisten (RS). Pati RDS dan SDS lebih mudah dicerna dan diserap oleh tubuh sehingga dapat meningkatkan kadar glukosa darah, sedangkan RS merupakan pati yang tidak dapat dicerna oleh enzim amilase dan dapat melewati saluran pencernaan atas hingga sampai ke kolon dan difermentasi oleh mikroba kolon (Birt et al., 2013). Lauretin dan Edwards (2013) melaporkan bahwa terdapat 4 macam RS yaitu RS tipe I (RS1) adalah jenis pati yang terperangkap di dalam matriks sel, seperti pati pada polong-polongan. RS tipe II (RS2) adalah pati alami yang berupa granula pati, contohnya pati jagung yang kaya amilosa, pati kentang mentah dan pati pisang mentah. RS tipe III (RS3) adalah pati yang sudah mengalami retrogradasi karena pemanasan dan pendinginan berulang-ulang. RS tipe IV (RS4) adalah pati yang telah dimodifikasi secara kimia. RS tipe V (RS5) terbentuk dari kompleks amilosa-lemak.

Kadar RS dalam pati alami umumnya tergolong rendah, sehingga perlu ditingkatkan melalui proses modifikasi pati. Berbagai penelitian telah banyak dilakukan untuk meningkatkan kadar pati resisten baik secara fisik maupun kimia. Zhao dan Lin (2009) melaporkan bahwa pati pisang yang dihidrolisis dengan $\mathrm{HCl} 1 \mathrm{~N}$ selama 6 jam yang dilanjutkan dengan proses pemanasan pada $121^{\circ} \mathrm{C}$ selama 1 jam dan pendinginan pada $4^{\circ} \mathrm{C}$ (proses dilakukan sebanyak 3 siklus) meningkatkan kadar RS3 dari $1,51 \%$ menjadi $16,02 \%$. Pati jagung yang dihidrolisis dengan asam sitrat $0,1 \mathrm{M}$ selama 12 jam yang dilanjutkan dengan proses pemanasan pada $121^{\circ} \mathrm{C}$ selama 20 menit dan pendinginan $4^{\circ} \mathrm{C}$ dengan jumlah siklus yang sama juga meningkatkan kadar RS3 dari 8,0\% menjadi 11,0\%. Mun dan Shin (2006) melaporkan bahwa pati jagung yang dihidrolisis dengan $\mathrm{HCl} 0,1 \mathrm{~N}$ selama 6 jam menyebabkan peningkatan kadar RS3 menjadi 13,8-14,9\%. Disamping itu, Faridah (2011) mengemukakan bahwa hidrolisis $\mathrm{HCl} 2,2 \mathrm{~N}\left(2 \mathrm{jam}, 35^{\circ} \mathrm{C}\right)$, debranching pullulanase $10,4 \mathrm{U} / \mathrm{g}$ pati $\left(50^{\circ} \mathrm{C}, 24 \mathrm{jam}\right)$ dilanjutkan 3 siklus pemanasan pendinginan dapat meningkatkan kadar RS pati garut dari 2,12\% hingga $39,3 \%$.

Selain dipengaruhi oleh kadar pati dan rasio amilosa dan amilopektinnya, kadar pati resisten juga dipengaruhi oleh teknik modifikasi pati yang digunakan. Tujuan dari penelitian ini adalah untuk mengetahui pengaruh jumlah siklus autoclavingcooling, dan heat moisture treatment terhadap peningkatan kadar RS3 dan karakteristik kimia pati daluga modifikasi lainnya.

\section{BAHAN DAN METODE}

\section{Bahan}

Bahan baku yang digunakan dalam penelitian ini adalah umbi daluga yang diperoleh dari kepulauan Siau, Sulawesi Utara, Indonesia.

\section{Disain penelitian}

Penelitian ini dilakukan berdasarkan rancangan acak lengkap. Pati daluga dimodifikasi menggunakan hidrolisis asam (HA), dan debranching dengan pullulanase (D). Selanjutnya autoclaving-cooling (AC) dengan 1 dan 3 siklus, dengan dan tanpa heat moisture treatment (HMT). Dengan demikian, dalam percobaan ini terdiri dari 5 perlakuan yaitu (1) pati alami, (2) HADAC1x, (3) HADAC1 + +HMT, (4) HADAC3x, (5) HADAC3x+ HMT. Setiap perlakuan diulang sebanyak 3 kali.

\section{Persiapan dan ekstraksi pati daluga (Modifikasi Jayakody et al., 2005)}

Umbi diiris dengan tebal $2-3 \mathrm{~cm}$ kemudian direndam dalam potasium metabisulfit $(50 \mathrm{mg} / \mathrm{L})$ (Jayakodi et al., 2005). Umbi daluga segar dibersihkan kemudian dihaluskan menggunakan mesin pemarut tanpa direndam terlebih daluhu dalam potasium metabisulfit $(50 \mathrm{mg} / \mathrm{L})$. Kemudian dilarutkan dalam air selama 10 menit, lalu disaring menggunakan kain saring. Proses tersebut diulang beberapa kali sampai air rendaman menjadi bening. Air rendaman tersebut didiamkan selama 24 jam. Endapan tepung daluga dicuci menggunakan $\mathrm{NaOH}$ (Merck, Germany) 0,05 M sampai bening, lalu dibilas menggunakan aquades. Untuk menetralkan $\mathrm{pH}$, ditambahkan $\mathrm{HCl}$ (Merck, Germany) 0,1 M kemudian dibilas menggunakan aquades. Suspensi pati daluga yang didapatkan disaring kembali lalu dikeringkan dalam oven pengering pada suhu $50^{\circ} \mathrm{C}$ selama 6 jam.

\section{Modifikasi pati daluga}

Pati alami daluga yang telah diekstraksi selanjutnya dimodifikasi melalui hidrolisis asam dan debranching dengan pullulanase, kemudian dilanjutkan dengan (1) AC 1 siklus dan HMT, (2) AC 3 siklus, (3) AC 3 siklus dan HMT. 


\section{Hidrolisis asam}

Sebanyak $150 \mathrm{~g}$ pati daluga disuspensikan dalam larutan $\mathrm{HCl}$ (Merck, Germany) 2,2 N (rasio 1:1) pada suhu $35^{\circ} \mathrm{C}$ selama 2 jam, sambil dilakukan pengadukan. Kemudian ditambahkan $\mathrm{NaOH}$ (Merck, Germany) $1 \mathrm{M}$ hingga mencapai $\mathrm{pH} 6,0$. Suspensi pati kemudian dikeringkan pada suhu $50^{\circ} \mathrm{C}$ selama 24 jam hingga mencapai kadar air 10-12\%.

\section{Autoclaving-cooling dan debranching}

Sebanyak $80,0 \mathrm{~g}$ pati daluga hasil hidrolisis asam dibuat menjadi suspensi pati daluga $20 \%(\mathrm{~b} / \mathrm{v})$ dalam air destilata, kemudian dipanaskan pada suhu $80^{\circ} \mathrm{C}$ selama 5 menit. Pasta pati kemudian dipanaskan pada suhu $121^{\circ} \mathrm{C}$ selama 15 menit, lalu didinginkan selama 60 menit pada suhu ruang (29$30^{\circ} \mathrm{C}$ ). Pasta pati disimpan di refrigerator $4^{\circ} \mathrm{C}$ (Sharp SJ-F190M-TSK, Indonesia) selama 24 jam, kemudian dipanaskan kembali hingga suhu $50^{\circ} \mathrm{C}$.

Pasta pati diencerkan menggunakan buffer asetat dan campuran buffer asetat dengan enzim pullulanase (Sigma P-2986, Germany) dengan konsentrasi 10,4 U/g dengan perbandingan 1:1 (v:v) sampai konsentrasi $10 \%$ (b/v). Sampel diinkubasi selama 24 jam pada suhu $50^{\circ} \mathrm{C}$ dalam penangas air bergoyang (PolyScience, USA), kemudian dilakukan autoclaving-cooling sebanyak 2 siklus pada suhu $121^{\circ} \mathrm{C}$ dan $4^{\circ} \mathrm{C}$. Sampel dikeringkan pada freeze dry, kemudian sampel dihaluskan dan diayak menggunakan ayakan 80 mesh. Sampel disimpan dalam freezer pada suhu $-18^{\circ} \mathrm{C}$ sampai digunakan.

\section{Heat moisture treatment}

Sampel hasil modifikasi hidrolisis asam, debranching dan autoclaving-cooling ditambahkan akuades hingga mencapai kadar air 20\% kemudian disimpan dalam plastik tahan panas selama \pm 6 jam pada suhu ruang. Sampel diotoklaf (Tomy SX-300, High-Pressure Steam Sterilizer, Tomy Seiko Co, Ltd, Jepang) pada suhu $121^{\circ} \mathrm{C}$ selama 60 menit. Sampel dikeringkan dalam oven selama 24 jam pada suhu $50^{\circ} \mathrm{C}$, kemudian dihaluskan dan diayak menggunakan ayakan 80 mesh. Sampel disimpan dalam freezer $-18^{\circ} \mathrm{C}$ sampai digunakan.

\section{Analisis karakteristik kimia pati daluga modi- fikasi (PDM)}

Analisis karakteristik kimia PDM meliputi kadar total pati (Dubois et al., 1956) dan kadar RS3 (Goni et al., 1996) menggunakan metode sulfat-fenol, kadar amilosa (IRRI, 1978), kadar gula pereduksi (Miller, 1959) menggunakan metode DNS. Analisis ini menggunakan spektrofotometer (UV min 1240, Shimadzu, Jepang).

\section{Analisis statistik}

Data karakateritik kimia PDM dianalisis menggunakan analisis ragam (ANOVA) dan dilanjutkan dengan uji beda nyata jujur (BNJ) pada $\alpha=0,05$ jika nilai $F_{\text {hitung }}>F_{\text {tabel. }}$.

Analisis korelasi kadar pati, gula pereduksi, kadar amilosa, dan kadar RS3 daluga dilakukan menggunakan korelasi pearson. Hasil analisis koefisien korelasi pearson menunjukkan nilai korelasi pearson yang yang positif dan negatif. Koefisien korelasi pearson negatif menunjukkan bahwa variabel $X$ dan $Y$ memiliki hubungan terbalik, artinya jika nilai variabel $\mathrm{X}$ meningkat, maka variabel $\mathrm{Y}$ akan menurun dan berlaku sebaliknya. Koefisien korelasi pearson positif, artinya jika nilai variabel $\mathrm{X}$ meningkat, maka nilai variabel $Y$ meningkat pula. Interpretasi mengenai kekuatan hubungan antara dua variabel dilakukan berdasarkan pernyataan Matjjik dan Sumertajaya (2002) yang memberikan beberapa kriteria sebagai berikut: (0: tidak ada korelasi); $(>0-0,25$ : korelasi sangat lemah); $(>0,25-0,5$ : korelasi cukup); $(>0,5-0,75$ : korelasi kuat); $(>0,75-$ 0,99 : korelasi sangat kuat); (1: korelasi sempurna).

\section{HASIL DAN PEMBAHASAN}

\section{Kadar total pati PDM}

Perubahan kadar total pati daluga setelah dimodifikasi disebabkan proses hidrolisis asam, dan debranching menyebabkan terjadinya hidrolisis ikatan glikosidik baik pada fraksi amilosa maupun amilopektin dan menghasilkan fraksi linear rantai pendek dan gula-gula sederhana. Seperti halnya yang terjadi pada pati pisang (Leong et al., 2007), pati pisang (Nurhayati et al., 2014), pati singkong (Onyango dan Mutungi, 2008), pati garut (Faridah, 2011) bahwa modifikasi pati melalui hidrolisis asam dapat menghidrolisis ikatan glikosidik secara acak, sedangkan aktivitas enzim pullulanase dapat menghidrolisis ikatan glikosidik a-D-(1-6) pada fraksi amilopektin (Simsek dan Nehir, 2012) sehingga mampu meningkatkan fraksi molekul berantai lurus (amilosa rantai pendek). Modifikasi pati yang dilanjutkan dengan autoclaving-cooling dengan berbagai siklus dengan dan tanpa HMT menyebabkan penurunan kadar total pati daluga (Gambar 1). Hasil uji statistik menggunakan BNJ $(\alpha=0,05)$ menunjukkan bahwa perlakuan modifikasi pati berpengaruh signifikan terhadap penurunan kadar total pati jika dibandingkan dengan pati alami.

Peningkatan jumlah siklus $A C$ dan penggunaan HMT juga menyebabkan penurunan kadar pati pada pati daluga modifikasi. Hal ini dapat dilihat dari total pati yang dimodifikasi dengan HADAC1x $(79,31 \%)$ menurun menjadi 64,93\% (HADAC1x+HMT), begitupula dengan total pati yang dimodifikasi dengan HADAC $3 x$ dan HADAC3 + HMT masing-masing menjadi 69,26 dan 52,51\%. Penurunan tersebut disebabkan pemanasan pada otoklaf baik pada AC maupun HMT mengakibatkan peningkatan deg- 
radasi pati daluga melalui pemutusan ikatan glikosidik pada fraksi pati baik pada fraksi amilosa $(\alpha-1,4)$ maupun amilopektin $(\alpha-1,6)$. Dengan demikian, peningkatan jumlah $\mathrm{AC}$ dan penggunaan HMT dapat meningkatkan kadar gula-gula sederhana (Gambar 1) jika dibandingkan dengan pati alami $(1,27 \%)$ maupun HADAC1x $(9,67 \%)$ dan HADAC3x $(19,17 \%)$. Hal tersebut juga terjadi pada pati garut dengan kadar pati sebesar $61,11 \%$ setelah dimodifikasi melalui hidrolisis asam, debranching, dan 3 siklus autoclaving-cooling, namun menurun menjadi $56,23 \%$ setelah dilanjutkan dengan HMT (Slameut, 2015).

\section{Kadar amilosa}

Perubahan yang terjadi pada kadar amilosa pada pati daluga modifikasi dipengaruhi oleh modifikasi melalui hidrolisis asam (Leong et al., 2007) dan debranching (Simsek dan Nehir, 2012) sebagaimana telah dijelaskan di atas. Metode modifikasi pati daluga berpengaruh nyata (BNJ $\alpha=0,05$ ) terhadap peningkatan fraksi amilosa (Gambar 2).

Kadar amilosa tertinggi diperoleh ketika pati daluga dimodifkasi dengan HADAC1x (72,48\% bk). Namun terjadi penurunan kadar amilosa pati daluga modifikasi setelah dimodifikasi melalui HADAC3x $(43,29 \%$ bk) yang disebabkan proses pemanasan dalam autoclaving-cooling yang berulang menyebabkan terjadinya pemutusan ikatan glikosidik pada fraksi amilosa maupun amilopektin yang berulang pula sehingga akan terjadi peningkatan kadar gula sederhana (Gambar 1), seperti halnya yang dilaporkan oleh Zaragoza et al. (2010) dan Hickman et al.
(2009) bahwa selama proses autoclaving-cooling terjadi 3 tahap hidrolisis pati yaitu gelatinisasi, pemutusan ikatan glikosidik, dan retrogradasi pati alami. Disamping itu, pemanasan pati di atas suhu gelatinisasi dapat menyebabkan pemutusan ikatan hidrogen dari struktur double helix molekul amilopektin (Sajilata et al., 2006), pelelehan daerah kristalin (Zabar et al., 2008), dan pelepasan amilosa dari granulanya (Zaragoza et al., 2010).

Penurunan kadar amilosa terjadi ketika pati daluga dimodifkasi melalui HADAC1x+HMT $(64,16 \%$ bk) dan HADAC3x+HMT $(36,47 \%$ bk) jika dibandingkan dengan HADAC1x dan HADAC3x. Hal tersebut disebabkan selama proses HMT terjadi interaksi antara amilosa-amilosa, amilopektin-amilopektin, serta amilosa-amilopektin. Selama HMT juga terjadi pemutusan ikatan glikosidik menjadi gula-gula sederhana (Chung et al., 2009) dan kemungkinan terjadi reaksi Maillard. Proses pemanasan pada $A C$ dan HMT dapat memicu reaksi Maillard karena selama proses tersebut pati akan dipanaskan pada suhu $121^{\circ} \mathrm{C}$. Erickson et al. (1981) melaporkan bahwa reaksi Maillard merupakan reaksi pencoklatan non enzimatis yang terjadi ketika terdapat gula pereduksi dan asam amino atau protein yang dipicu oleh suhu tinggi $\left(100-150^{\circ} \mathrm{C}\right)$. Asam amino atau protein dalam reaksi Maillard ini berasal dari enzim pullulanase yang digunakan dalam modifikasi awal dengan debranching. Selama reaksi Maillard, terjadi interaksi antara amilosa (gula pereduksi) dengan protein, sehingga akan terbentuk kompleks amilosa-protein. Kondisi ini menyebabkan penurunan kadar amilosa.

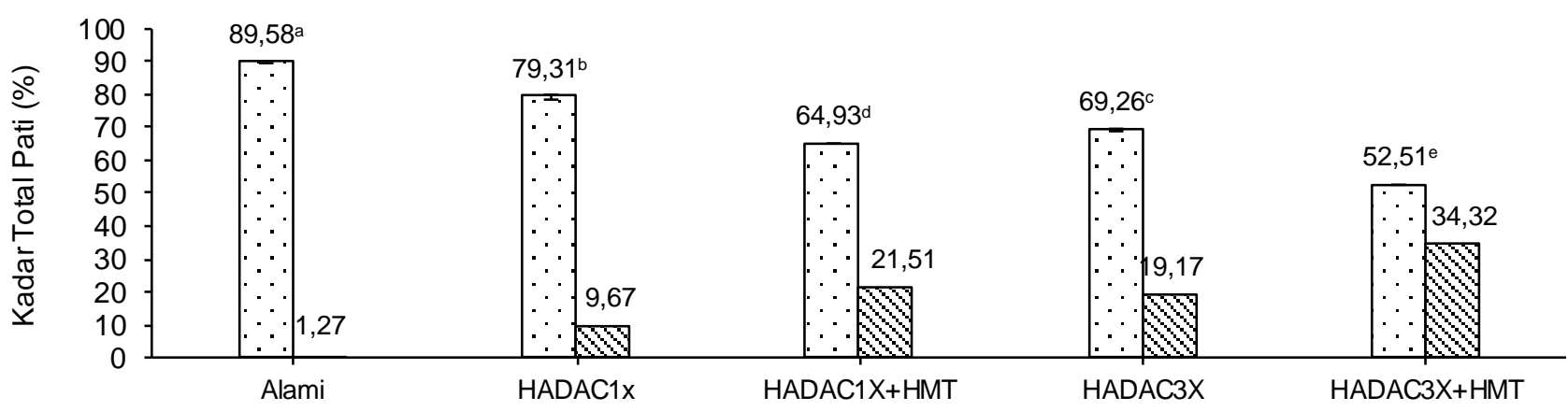

口Total pati $\mathbf{Q}$ total gula sederhana

Metode Modifikasi

Keterangan: HADAC1x = hidrolisis asam, debranching dengan pullulanase, autoclaving-cooling 1 siklus, HADAC1x+ $\mathrm{HMT}=$ hidrolisis as am, debranching dengan pullulanase, autoclaving-cooling 1 siklus dan Heat Moisture Treatment, $\mathrm{HADAC} 3 \mathrm{x}=$ hidrolisis as am, debranching dengan pullulanase, pemanasan-pendinginan bertekanan (AC) 3 siklus, $\mathrm{HADAC} 3 \mathrm{x}+\mathrm{HMT}=$ hidrolisis asam, debranching dengan pullulanase, pemanasan-pendinginan bertekanan (AC) 3 siklus dan Heat Moisture Treatment. Angka pada grafik yang disertai huruf yang berbeda menunjukkan berbeda nyata $(\mathrm{BNJ} \alpha=0,05)$

Gambar 1. Pengaruh metode modifikasi pati terhadap kadar pati daluga 


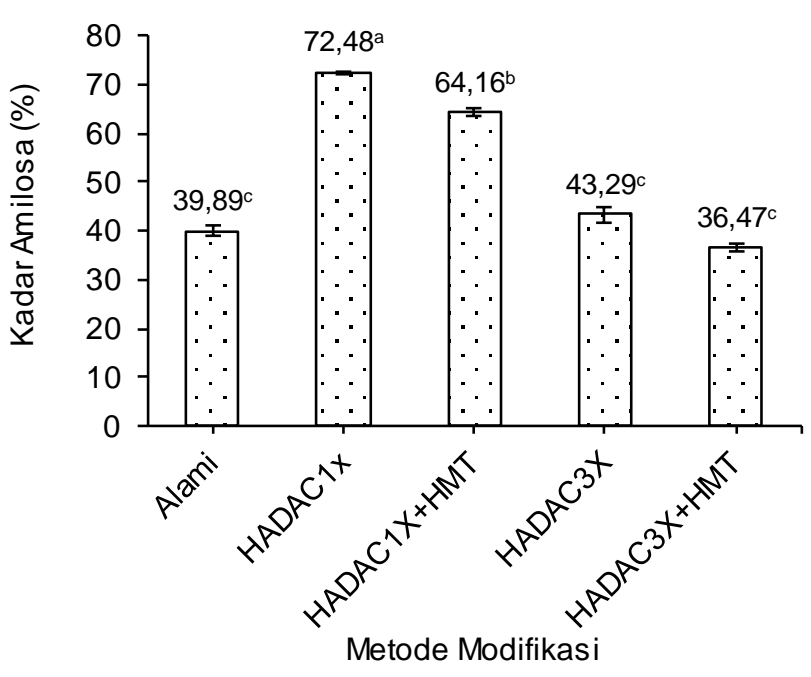

Keterangan: $\operatorname{HADAC} 1 \mathrm{x}=$ hidrolisis asam, debranching dengan pullulanase, autoclaving-cooling 1 siklus, $\mathrm{HADAC} 1 \mathrm{x}+\mathrm{HMT}=$ hidrolisis asam, debranching dengan pullulanase, autoclaving-cooling 1 siklus dan Heat Moisture Treatment, HADAC3x= hidrolisis asam, debranching dengan pullulanase, pemanasan-pendinginan bertekanan (AC) 3 siklus, HADAC $3 \mathrm{x}+\mathrm{HMT}=$ hidrolisis asam, debranching dengan pullulanase, pemanasan-pendinginan bertekanan (AC) 3 siklus dan Heat Moisture Treatment. Angka pada grafik yang disertai huruf yang berbeda menunjukkan berbeda nyata $(B N J \alpha=0,05)$

Gambar 2. Pengaruh metode modifikasi pati terhadap kadar amilosa pati daluga

\section{Kadar gula pereduksi}

Kadar gula pereduksi merupakan salah satu parameter yang dapat digunakan untuk mengetahui tingkat hidrolisis pati. Hidrolisis pati berhubungan dengan pemutusan ikatan glikosidik pati menjadi rantai glukan dengan ujung pereduksi. Jumlah rantai glukan dari hasil hidrolisis pati yang semakin banyak menunjukkan kadar gula pereduksi yang semakin tinggi. Gula pereduksi dapat berupa gula sederhana, disakarida maupun glukan rantai pendek. Dengan demikian, sebagian glukan rantai pendek maupun gula-gula sederhana yang dihasilkan melalui hidrolisis asam (Leong et al., 2007) dan debranching (Simsek dan Nehir, 2012) pati daluga merupakan gula pereduksi.

Proses AC dan HMT dapat menghasilkan gugus aldosa dan fraksi linear rantai pendek yang terukur sebagai gula pereduksi, karena selama proses-proses tersebut terjadi pemutusan sebagian kecil ikatan glikosidik baik pada amilosa maupun amilopektin (Pratiwi, 2016). Dengan demikian, kadar gula pereduksi pati daluga modifikasi mengalami peningkatan. Hasil uji statistik menunjukkan bahwa metode modifikasi pati daluga berpengaruh nyata terhadap rata-rata kadar gula pereduksi (BNJ $\alpha=0,05)$. Gambar 3 menunjukkan bahwa kadar gula pereduksi pati daluga alami $(2,86 \%$ bk) mengalami peningkatan setelah dimodifkasi menggunakan HADAC1x $(8,61 \%$ bk) dan HADAC1x+HMT $(14,48 \%$ bk). Hal ini menunjukkan bahwa pemutusan ikatan glikosidik pada amilosa maupun amilopektin selama proses AC (Zaragoza et al., 2010; Mun dan Shin 2006) dan HMT (Chung et al., 2009) menghasilkan fraksi linear rantai pendek dan gula-gula sederhana yang memiliki ujung pereduksi. Proses autoclavingcooling yang berulang dapat menyebabkan terjadinya peningkatan penyusunan amilosa-amilosa dan amilosa-amilopektin dan peningkatan pembentukan kristalin yang lebih sempurna yang berakibat pada peningkatan kadar RS3 (Leong et al., 2007).

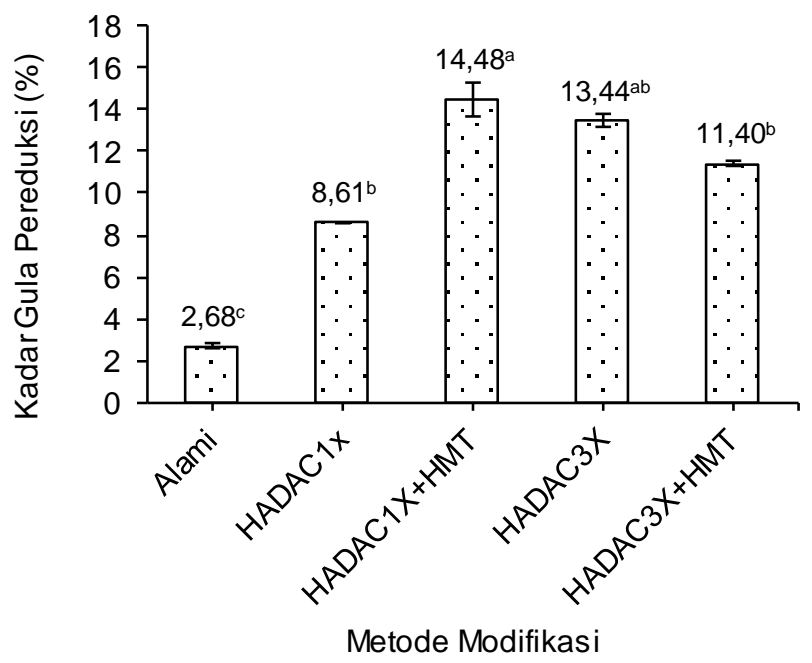

Keterangan: $\mathrm{HADAC} 1 \mathrm{x}=$ hidrolisis asam, debranching dengan pullulanase, autoclaving-cooling 1 siklus, $\mathrm{HADAC} 1 \mathrm{x}+\mathrm{HMT}=$ hidrolisis asam, debranching dengan pullulanase, autoclaving-cooling 1 siklus dan Heat Moisture Treatment, HADAC3x= hidrolisis asam, debranching dengan pullulanase, pemanasan-pendinginan bertekanan (AC) 3 siklus, HADAC $3 \mathrm{x}+\mathrm{HMT}=$ hidrolisis asam, debranching dengan pullulanase, pemanasan-pendinginan bertekanan (AC) 3 siklus dan Heat Moisture Treatment. Angka pada grafik yang disertai huruf yang berbeda menunjukkan berbeda nyata $(B N J \alpha=0,05)$

Gambar 3. Pengaruh metode modifikasi pati terhadap kadar gula pereduksi pati daluga

Namun, ketika pati daluga dilanjutkan dengan modifikasi menggunakan HADAC3x dan HADAC3x+ HMT mengalami penurunan kadar gula pereduksi masing-masing menjadi 13,44\% (bk) dan 11,40\% (bk) jika dibandingkan dengan HADAC1x+HMT $(14,48 \%$ bk). Penurunan kadar gula pereduksi tersebut disebabkan terjadinya reaksi Maillard sebagai akibat pemanasan pada suhu $121^{\circ} \mathrm{C}$ selama proses HADAC3x dan HADAC3x+HMT, seperti yang telah dijelaskan di atas. Pada proses HADAC1x dan 
HADAC1x+HMT juga kemungkinan terjadi reaksi Maillard karena pada proses tersebut juga melibatkan proses pemanasan suhu tinggi $\left(121^{\circ} \mathrm{C}\right)$. Namun, tingkat reaksi Maillard yang terjadi berbeda dengan HADAC3x dan HADAC3x+HMT. Erickson et al. (1981) melaporkan bahwa suhu dan waktu pemanasan merupakan faktor-faktor yang mempengaruhi reaksi Maillard. Semakin lama dan semakin tinggi suhu pemanasan, maka reaksi Maillard yang terjadi semakin banyak. Hal ini dapat ditunjukkan melalui data gula pereduksi pati daluga modifikasi pada HADAC1x+HMT (14,48\% bk), HADAC3x (13,44\% bk), dan HADAC $3 x+$ HMT $(11,40 \%$ bk). Secara statistik, kadar gula pereduksi pada HADAC1 $x+H M T$ dan HADAC3x tidak berbeda nyata.

\section{Kadar pati resisten tipe III (RS3)}

Berbeda dengan kadar pati daluga yang dimodifikasi, kadar RS3 daluga mengalami peningkatan setelah dimodifkasi secara fisik dan kimia. Peningkatan tersebut dapat dilihat dari nilai kadar pati resisten daluga alami dibandingkan dengan kadar pati resisten pati daluga modifikasi (Gambar 4). Peningkatan kadar RS3 daluga setelah proses modifikasi menunjukkan bahwa selama proses terjadi perubahan struktur pada pati daluga sehingga menjadi resisten terhadap enzim-enzim pencernaan maupun asam lambung.

Rendahnya kadar RS pada pati daluga alami disebabkan kemungkinan besar RS yang terukur pada pati daluga alami merupakan RS tipe 2 yang secara alami terdapat dalam pati daluga, sedangkan RS yang terukur pada pati daluga modifikasi merupakan RS3 yang terbentuk selama proses modifikasi fisik maupun kimia. RS yang terukur pada pati modifikasi hanya RS3 karena RS tipe 1 akan hilang selama proses pemurnian pati dan RS tipe 2 akan terhidrolisis oleh enzim dan terlarut selama persiapan sampel dan analisis RS.

Pati daluga yang dimodifkasi dengan HADAC1x memiliki kadar RS3 40,47\% (bk) dan HADAC1x+ HMT memiliki kadar RS3 42,37\% (bk). Seperti yang telah disebutkan sebelumnya bahwa asam dapat menghidrolisis ikatan glikosidik secara acak baik pada amilosa maupun amilopektin, sedangkan enzim pullulanase dapat menghidrolisis ikatan percabangan $(\alpha-1,6)$ pada amilopektin sehingga terjadi peningkatan fraksi linear rantai pendek. Proses autoclaving-cooling dapat menyebabkan terjadinya retrogradasi fraksi amilosa, dimana kadar RS3 secara proporsional berbanding lurus dengan kandungan amilosa dalam bahan pangan (Shu et al. 2007). Selanjutnya dalam proses AC melibatkan proses pemanasan suhu tinggi $\left(121^{\circ} \mathrm{C}\right)$ dalam otoklaf, mengakibatkan pati tergelatinisasi secara sempurna dan proses penyimpanan suhu rendah $\left(4^{\circ} \mathrm{C}\right)$ dari pasta pati yang dihasilkan akan mempercepat terjadinya retrogradasi pati (Faridah, 2011,
Kim dan Kwak 2009). Proses retrogradasi pati tersebut menyebabkan terjadinya rekristalisasi dan meningkatkan pembentukan RS3. Disamping itu, Pongjanta et al. (2009) juga melaporkan bahwa proses debranching meningkatkan kadar RS3 pati beras tinggi amilosa sebanyak 4 kali lipat lebih tinggi dibandingkan dengan yang diproses tanpa debranching pada kondisi autoclaving-cooling yang sama. Dengan demikian, proses debranching memberikan kontribusi yang berarti dalam peningkatan kadar RS3 daluga yang terbentuk.

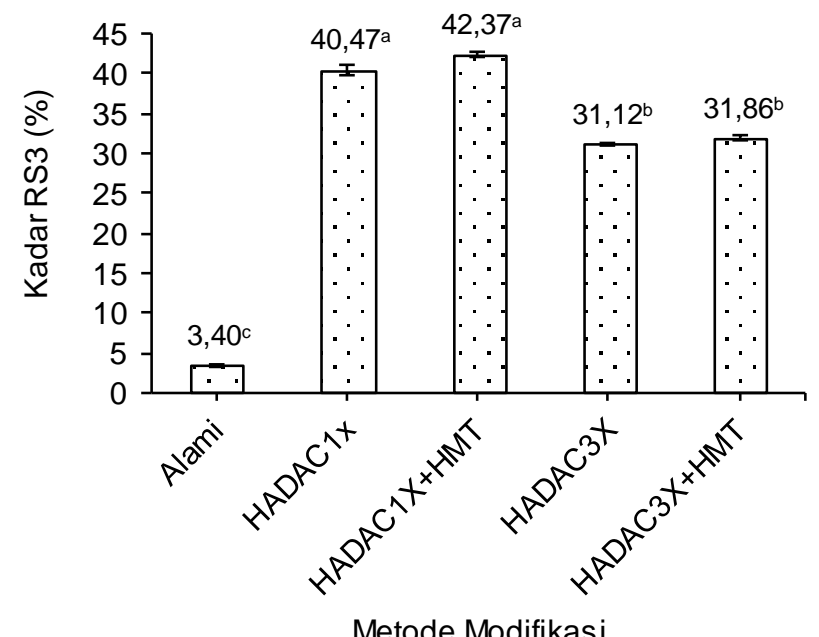

Keterangan: HADAC1x = hidrolisis asam, debranching dengan pullulanase, autoclaving-cooling 1 siklus, $\mathrm{HADAC} 1 \mathrm{x}+\mathrm{HMT}=$ hidrolisis asam, debranching dengan pullulanase, autoclaving-cooling 1 siklus dan Heat Moisture Treatment, HADAC $3 \mathrm{x}=$ hidrolis is asam, debranching dengan pullulanase, pemanasanpendinginan bertekanan (AC) 3 siklus, HAD$\mathrm{AC} 3 \mathrm{x}+\mathrm{HMT}=$ hidrolisis asam, debranching dengan pullulanase, pemanasan-pendinginan bertekanan (AC) 3 siklus dan Heat Moisture Treatment. Angka pada grafik yang disertai huruf yang berbeda menunjukkan berbeda nyata (BNJ $\alpha=0,05)$

Gambar 4. Pengaruh metode modifikasi pati terhadap kadar pati resisten daluga

Selain itu, kristalisasi juga terjadi selama proses HMT melalui pembentukan double helix baru di antara molekul-molekul amilosa. Double helix yang terbentuk tersebut akan membentuk pembesaran (agregasi) dengan double helix pada molekul amilosa lainnya melalui ikatan hidrogen sehingga membentuk kristalit dan struktur pati yang kompak (Mutungi et al., 2009; Ji et al., 2015). Dalam proses HMT juga terjadi interaksi antara amilosa-amilosa, amilopektin-amilopektin, dan amilosa-amilopektin membentuk struktur yang lebih kompak dan stabil (Zeng et al., 2015). 
Namun, pati daluga yang dimodifikasi secara HADAC $3 x$ dan HADAC3X+HMT masing-masing memiliki kadar pati resisten 31,12 dan $31,86 \%$ (bk). Hal ini menunjukkan bahwa terjadi penurunan kadar pati resisten jika dibandingkan dengan HADAC1x $(40,47 \%$ bk) dan HADAC1x+HMT (42,37\% bk). Penurunan tersebut terjadi karena peningkatan jumlah siklus AC dapat menyebabkan pemotongan pada ikatan glikosidik sehinggan jumlah fraksi amilosa menurun (Gambar 2). Sajilata et al. (2006) melaporkan bahwa faktor-faktor yang mempengaruhi proses pembentukan RS3 adalah nisbah pati dan air atau konsentrasi pati, suhu autoclaving, jumlah siklus autoclaving-cooling, nisbah amilosa dan amilopektin, panjang rantai amilosa. Hal ini sejalan dengan hasil penelitian ini bahwa penurunan kadar pati daluga modifikasi (Gambar 1) dan kadar amilosa pati daluga modifikasi (Gambar 2) menyebabkan penurunan kadar RS3 yang terbentuk. Penurunan kadar amilosa menyebabkan semakin sedikit jumlah amilosa yang tergelatinisasi dan teretrogrdasi selama proses HADAC3x serta dalam proses HADAC $3 x+H M T$ semakin sedikit pula jumlah amilosa-amilosa yang berinteraksi membentuk struktur yang kompak dan stabil.
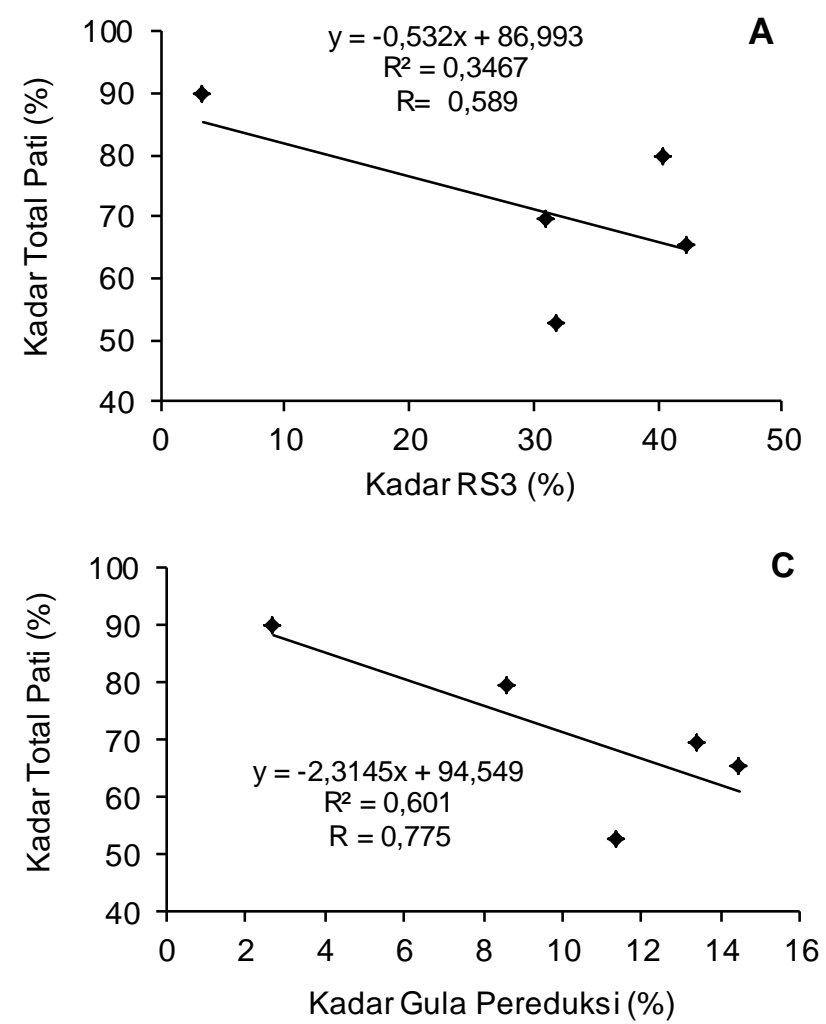

Korelasi kadar pati, gula pereduksi, kadar amilosa, dan kadar RS3 daluga

Hasil analisis koefisien korelasi pearson terhadap berbagai parameter karakteristik kimia PDM menunjukkan bahwa setiap parameter memiliki korelasi dengan parameter yang lain, namun dengan tingkat korelasi yang berbeda-beda (Gambar 5).

Hasil analisis korelasi menunjukkan bahwa kadar total pati dan kadar RS3 memiliki korelasi yang sangat kuat dengan kadar gula pereduksi dengan nilai koefisien korelasi masing-masing 0,775 (Gambar 5C) dan 0,821 (Gambar 5D). Penurunan kadar total pati akibat perlakuan hidrolisis asam, debranching, autoclaving-cooling, dan HMT berkorelasi negatif dengan kadar gula pereduksi. Korelasi ini sesuai dengan hasil penelitian yang dilaporkan oleh Nurhayati et al. (2014) pada tepung pisang. Pemutusan ikatan glikosidik terjadi melalui modifikasi pati daluga melalui hidrolisis asam selama 2 jam pada amilosa maupun amilopektin, dan debranching pada amilopektin serta pemanasan otoklaf pada proses autoclaving-cooling dan HMT pada amilosa maupun amilopektin dan berkontribusi terhadap pembentukan gula pereduksi.

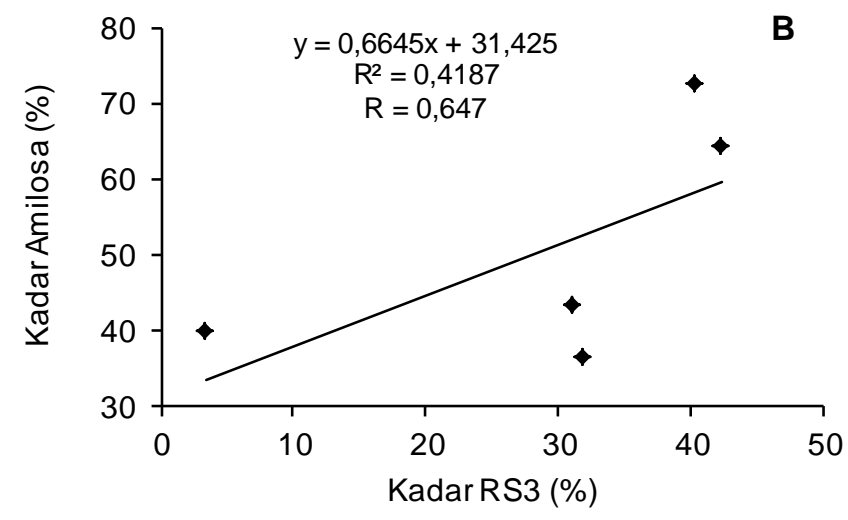

Gambar 5. Kurva korelasi hubungan antara berbagai parameter kimia PDM; (A) korelasi antara kadar RS3
dengan kadar total pati, (B) korelasi antara kadar RS3 dengan kadar amilosa, (C) korelasi

Gambar 5. Kurva korelasi hubungan antara berbagai parameter kimia PDM; (A) korelasi antara kadar RS3
dengan kadar total pati, (B) korelasi antara kadar RS3 dengan kadar amilosa, (C) korelasi antara kadar gula pereduksi dengan kadar total pati, (D) korelasi antara kadar RS3 dengan kadar gula pereduksi

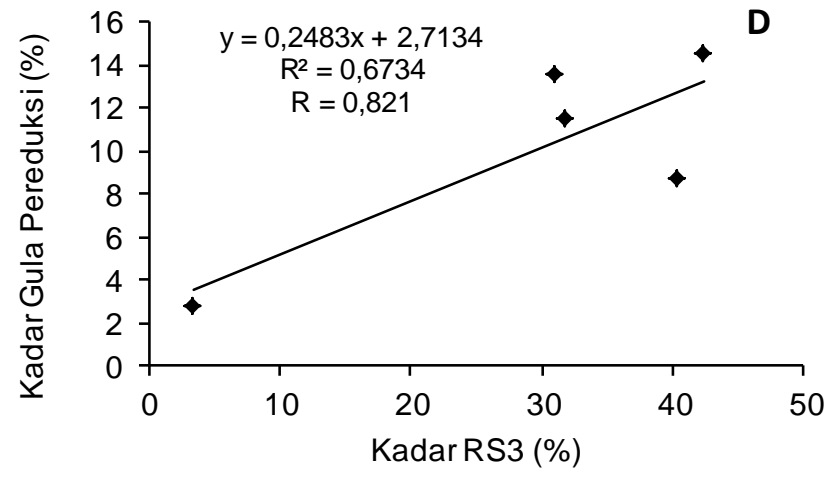


Hasil analisis korelasi menunjukkan bahwa kadar gula pereduksi memiliki korelasi yang sangat kuat terhadap kadar RS3 dengan nilai korelasi mencapai 0,821 (Gambar 5D). Peningkatan kadar gula pereduksi berkorelasi positif dengan terbentuknya RS3. Hal ini menunjukkan bahwa peningkatan gula pereduksi menyebabkan peningkatan kadar RS3 pula. Hal ini disebabkan gula pereduksi dapat berupa fraksi linear rantai pendek. Dengan demikian, peningkatan gula pereduksi berkontribusi terhadap peningkatan kadar amilosa. Hal ini sesuai dengan hasil analisis pearson bahwa kadar gula pereduksi berkorelasi positif, meskipun kedua variabel tersebut memiliki korelasi yang sangat lemah $(R=0,209)$. Dengan demikian, peningkatan gula pereduksi dalam PDM tidak berpengaruh signifikan terhadap peningkatan kadar amilosa.

Disamping itu, peningkatan kadar amilosa menyebabkan peningkatan kadar RS3 daluga. Hal ini sesuai dengan hasil analisis korelasi yang ditunjukkan pada Gambar 5B bahwa kadar amilosa memiliki korelasi yang kuat terhadap RS3 dengan nilai koefisien korelasi sebesar 0,647 dan berkorelasi positif. Hal ini sesuai dengan hasil penelitian Faridah (2011) bahwa semakin banyak fraksi linear rantai pendek, maka semakin banyak yang tergelatinisasi sempurna dan teretrogradasi dalam proses autoclaving-cooling dan Shu et al. (2007) menyebutkan bahwa kadar RS3 pati beras secara proporsional berbanding lurus dengan kandungan amilosa dalam bahan pangan. Disamping itu, selama proses HMT terjadi peningkatan interaksi antara amilosa-amilosa, amilosa-amilopektin, serta amilopektin-amilopektin membentuk struktur yang lebih kompak dan stabil (Faridah, 2011). Umumnya, interaksi antara amilosa-amilosa lebih mudah terjadi dibandingkan dengan amilosa-amilopektin dan amilopektin-amilopektin (Zavareze dan Dias, 2011). Kondisi tersebut menyebabkan peningkatan kadar RS3 daluga.

\section{KESIMPULAN}

Modifikasi pati daluga melalui kombinasi hidrolisis asam, debranching, autoclaving-cooling (1 dan 3 siklus) dengan dan tanpa heat moisture treatment dapat meningkatkan kadar RS3, kadar amilosa dan kadar gula pereduksi. Teknologi proses modifikasi pati daluga yang efektif dan efisien dalam meningkatkan kadar RS3 daluga yaitu melalui hidrolisis asam (2,2 $\mathrm{N} \mathrm{HCl}, 2$ jam), debranching dengan pullulanase $(10,4 \mathrm{U} / \mathrm{g}$ pati), autoclavingcooling 1 siklus $\left(121^{\circ} \mathrm{C}, 15\right.$ menit) dengan peningkatan RS3 sebanyak 11,9 kali lipat (dari 3,40\% menjadi $40,47 \%$ ).

\section{DAFTAR PUSTAKA}

Birt DF, Boylston T, Hendrich S, Jane JL, Hollis J, Li $\mathrm{Li}$, McCleeand J, Moore S, Phillips GJ, Rowling M, Schalinski K, Scott MP, Whitley EM. 2013. Resistant starch: promise for improving human health: a review. Adv in Nutr 4: 587-601. DOI: 10.3945/an.113.004325.

Chung HJ, Liu Q, Hoover R. 2009. Impact of annealing and heat-moisture treatment on rapily dogestible, slowly digestible and resistant starch level in native and gelatinized corn, pea and lentil starches. Carbohyd Polym 75: 436447. DOI: 10.1016/j.carbpol.2008.08.006.

Dubois M, Gilles KA, Hamilton JK, Rebers PA, Smith F. 1956. Calorimetric method for determination of sugars and related substances. Anal Chem 28: 350-356. DOI: 10.1021/ac60111a017.

Erickson C, Asp NG, Theander O. 1981. Maillard reaction in food: chemical, physiological and technological aspect. Prog Food Nutr Sci 5: 1-6.

Faridah DN. 2011. Perubahan Karakteristik Kristalin Pati Garut (Marantha arundinaceae L.) dalam Pengembangan Pati Resisten Tipe III. [Disertasi]. Bogor: Fakultas Teknologi Pertanian, Institut Pertanian Bogor.

Goni L, Garcia-Diaz L, Manas E, Saura-Calixto F. 1996. Analysis of resistant starch: A method for food and food products. Food Chem 56: 445449. DOI: 10.1016/0308-8146(95)00222-7.

Hickman BE, Srinivas J, Yuan Y. 2009. Autoclave and $\beta$-amylolysis lead to reduced in vitro digestibility of starch. J Agr Food Chem 57: 7005-7012. DOI: 10.1021/jf9010164.

[IRRI] International Rice Research Institute. 1978. Rice Research and Production in China: An IRRI Team's View. International Rice Research Institute, Los Banos (PH).

Jackson GVH. 2008. Regeneration guidelines: major aroids. In: Dulloo ME, Thormann I, Jorge MA, Hanson J, Editors. Crop Specific Regeneration Guidelines [CD-ROM]. 16 p. CGIAR SystemWide Genetic Resource Programme, Rome, Italy.

Jayakodi L, Hoover R. Liu Q, Weber E. 2005. Sudies on tuber and root starches. Structure and physicochemical properties of innala (Solenostemon rotundifolius) starches grown in Sri Lanka. Food Res Int 38: 615-629. DOI: 10.10 16/j.foodres.2004.11.015.

Ji N, Li, Qiu C, Li G, Sun Q, Xiong L. 2015. Effects of heat moisture treatment oh the physicochemical properties of strach nanoparticles. Carbohyd Polym 117: 605-609. DOI: 10.1016/j. carbpol.2014.10.005. 
Kim SK, Kwak JE. 2009. Formation of resistant starch in corn starch and estimation of its content from physicochemical properties. Starch/Stärke 61: 514-519. DOI 10.1002/st ar.200800120.

Lauretin A, Edwards CA. 2013. Fiber: resistant starch and oligosaccharides. Encyclop Human Nutr 2: 322-329. DOI: 10.1016/B978-0-12-3750 83-9.00109-4.

Leong $\mathrm{YH}$, Karim AA, Norziah $\mathrm{MH}$. 2007. Effect of pullulanase debranching of sago (Metroxylon sagu) starch at subgelatinization temperature on the yield of resistant starch. Starch/Starke 59: 21-32. DOI: 10.1002/star.200600554.

Matjjik A, Sumertajaya IM. 2002. Perancangan Percobaan dengan Aplikasi SAS dan Minitab. 67-68. Bogor: IPB Press.

Miller GL. 1959. Use of dinitrosalicylic acid reagent for determination of reducing by sugar. Anal Chem 31: 426-428. DOI: 10.1021/ac60147a 030.

Mun SH, Shin M. 2006. Mild hydrolysis of resistant starch from maize. Food Chem 96: 115-121. DOI: 10.1016/j.foodchem.2005.02.015.

Mutungi C, Rost F, Onyango C, Jaros D, Rohma $\mathrm{H}$. 2009. Crystallinity, thermal and morphological characteristics of resistant starch type III produced by hydrothermal treatment of debranched cassava starch. Starch/Stärke 61: 634-645. DOI: 10.1002/star.200900167.

Nurhayati, Jenie BSL, Widowati S, Kusumaningrum HD. 2014. Komposisi kimia dan kristalinitas tepung pisang termodifikasi secara fermentasi spontan dan siklus pemanasan bertekananpendinginan. Agritech 34: 146-150. DOI: 10.2 2146/agritech.9504.

Onyango C, Mutungi C. 2008. Synthesis and in vitro digestion of resistant starch type III from enzimatically hydrolysed cassava starch. Int $\mathrm{J}$ Food Sci Tech 43: 1860-1865. DOI: 10.1111/j. 1365-2621.2008.01764.x.

Pongjanta J, Utaipattanaceep O, Naivikul, Piyachomkwan K. 2009. Effect of preheated treatments on physicochemical properties of resistant starch type III from pullulanase hydrolysis of high amylose rice starch. Am J Food Technol 4: 79-89. DOI: 10.3923/ajft. 2009.79.89.

Pratiwi M. 2016. Structural Changes of Arrowroot Starch (Marantha arundinacea I.) as the Impact of Multiple Treatments by acid Hydrolysis, Debranching, Autoclaving-cooling Cycles, and
Heat Moisture Treatment (HMT). [Tesis]. Bogor: Fakultas Teknologi Pertanian, Institut Pertanian Bogor.

Sajilata MG, Singhal RS, Kulkarni PR. 2006. Resistant starch: a review. Compr Rev Food Sci Food S 5: 1-17. DOI: 10.1111/j.1541-4337.200 6.tb00076.x.

Sharma A, Yadaf BS, Ritika. 2008. Resistant strach: Physiologycal roles and food applications. $\mathrm{Cr}$ Rev Food Sci 24: 193-234.

Slameut F. 2015. Modifikasi Pati Garut (Marantha arundinaceae L.) dengan Asam, Enzim dan Perlakuan Fisik untuk Memproduksi Pati Resisten Tipe 3 (RS3). [Skrips] Fakultas Teknologi Pertanian, Institut Pertanian Bogor.

Shu X, Jia L, Gao J, Sing Y, Zhao H, Nakamura Y, Wu D. 2007. The influence of chain length of amilopectin on resistant starch in rice (Oryza sativa L). Starch/Starke 59: 504-509. DOI: 10.1002/star.200700640.

Simsek S, Nehir SEL. 2012. Production resistant starch from taro (Colocasia esculenta L. Schott) corm and determination of its health by in vitro methods. Carbohyd Polym 90: 1204-1209. DOI: 10.1016/j.carbpol.2012.06.039.

Zabar S, Shimoni E, Peled HB. 2008. Development of nanostructure in resistant starch type III during thermal treatments and cycling. J Macro Biosci 8: 163-170. DOI: 10.1002/mabi.200700 183.

Zaragoza EF, Riquelme-Navarrete MJ, SanchezZapata E, Perez-Alvarez JA. 2010. Resistant starch as functional ingredient: A review. Food Res Int 43: 931-342. DOI: 10.1016/j.foodres. 2010.02.004.

Zavareze EF, Dias ARG. 2011. Impact of heat moisture treatment and annealing in starches: a review. Carbohyd Polym 83: 317-328. DOI: 10.1016/j.carbpol.2010.08.064.

Zeng F, Ma F, Kong F, Gao Q, Yu S. 2015. Physicochemical properties and digestibility of hydrothermally treated waxy rice starch. Food Chem 172: 92-98. DOI: 10.1016/j.foodchem.2014.09. 020.

Zhao XH, Lin Y. 2009. The impact of coupled acid or pullulanase debranching on the formation of resistant starch from maize starch with autoclaving-cooling cycles. Eur Food Res Technol 230: 179-184. DOI 10.1007/s00217009-1151-8. 